\title{
EVALUATION OF THE SEDATIVE AND ANTICONVULSANT PROPERTIES OF THREE CAMEROONIAN PLANTS
}

\author{
Fleur Clarisse Moto Okomolo*, Joseph Tanyi Mbafor $^{1 \dagger}$, Elisabeth Ngo Bum ${ }^{2 \ddagger a}$, Nadège \\ Kouemou $^{3 \S}$, Antoine Kavaye Kandeda ${ }^{2 * \star}$, Emmanuel Talla ${ }^{4 \dagger \dagger}$, Théophile Dimo ${ }^{3 \neq \ddagger}$, Alice \\ Rakotonirira $^{3 \S \S}$, Silvère Vincent Rakotonirira ${ }^{3 * \star *}$
}

${ }^{1}$ Department of Organic Chemistry, Faculty of Science, University of Yaoundé I, P.O. Box 812 Yaoundé, Cameroon, ${ }^{2}$ Department of Biological Sciences, Faculty of Science, University of Ngaoundéré, P.O. Box 565 Ngaoundéré, Cameroon, ${ }^{3}$ Department of Animal Biology and Physiology, Faculty of Science, University of Yaoundé I, P.O. Box 812 Yaoundé, Cameroon, ${ }^{4}$ Department of Chemistry, Faculty of Sciences, University of Ngaoundéré, Cameroon.

*E-mail: eli bum@yahoo.fr

\begin{abstract}
Millettia thonningii, Ocinum sanctum and Securitaca longepedunculaca are used in traditional medicine in Cameroon to treat epilepsy, insomnia and headaches. Animal models of epilepsy (maximal electroshock (MES), n-methyl-d-aspartate (NMDA), pentylenetetrazol (PTZ), isonicotinic hydrazide acid (INH), picrotoxine (PIC) and strychnine (STR)-induced convulsions or turning behavior were used to evaluate anticonvulsant activity while diazepam-induced sleep test was used to evaluate sedative activity of the plants. Four doses of extracts were used for each plant $(100,200,500$ and $1000 \mathrm{mg} / \mathrm{kg})$. At a dose of $1000 \mathrm{mg} / \mathrm{kg}$, Millettia thonningii protected 60 and $90 \%$ of mice against MES and PTZ-induced convulsions, respectively. At the same dose, Millettia thonningii also protected $80 \%$ of mice against NMDA-induced turning behavior. At a dose of $1000 \mathrm{mg} / \mathrm{kg}$, Ocinum sanctum provided complete protection against MES, PIC and STR- induced convulsions and $83.3 \%$ of protection in PTZ test. Securitaca longepedunculata completely protected (100\%) mice in PIC test at a dose of $200 \mathrm{mg} / \mathrm{kg}$, in MES test at a dose of $500 \mathrm{mg} / \mathrm{kg}$ and in PTZ test at a dose of $1000 \mathrm{mg} / \mathrm{kg} .66 .7 \%$ of mice were protected against STRinduced convulsions. All the three plants showed also sedative properties for they increased significantly and in a dose dependent manner the total sleep time induced by diazepam. The total sleep time of the control groups was multiplied by a factor of 3 at least by each extract. The presence of sedative and anticonvulsant activity in the three plants could explain their use in traditional medicine in the treatment of epilepsy and insomnia in Cameroon.
\end{abstract}

Keywords: Epilepsy; Insomnia; Traditional medicine.

\section{Introduction}

Milletia thonningii Baker (Fabaceae) (M. thonningii) and Securitaca longepedunculata Fres (Polygalaceae) (S. longepedunculata) are deciduous trees of 3-10 meter high, often found in savannah and forest areas in Cameroon and other countries in Africa, Ghana, Ivory Coast, Nigeria, Senegal and Togo (Arbonnier, 2000; Hutchinson and Dalziel,1958). Ocimum sanctum Lam (Lamiaceae) (O. sanctum) is a soudano-sahelian herb of $80 \mathrm{~cm}$ high also found in Africa (Geetha et al., 2004; Gupta et al., 2007). M. thonningii, O. sanctum and S. longepedunculata are used empirically in many countries in Africa and particularly in Cameroon to treat various diseases like epilepsy, insomnia, headaches, pains, fevers, heartaches, pneumonia, cold, stomachaches, allergy, worms, dysentery, rheumatism, jaundice, bronchitis, itch, intestinal obstruction, tuberculosis, leprosies (Abbiw, 1990; Arbonnier, 2000; Geetha et al., 2004; Gupta et al., 2007; Hutchinson and Dalziel, 1958; Irvine, 1961; Singhal et al., 1982). Knowing that in Sub-Saharan Africa, $70 \%$ of the populations are not able to pay for a modern Doctor or to buy a modern medicine, the use and the development of plants in traditional medicine are very essential in keeping the populations healthy. In addition, by using plants extracts, the side effects after treatment would be reduced, since plant extracts could possess fewer side effects (Vyawahare, et al., 2007). 
Documented evidence revealed antimalarial, molluscicidal, trypanocidal, antischistosomal, insecticidal, hypotensive, myorelaxant, antidepressant, analgesic, anti-inflammatory, hypoglycemic activities (Adebiyi et al., 2006; Aderbauer et al., 2008;Ancolio et al., 2002; Belmain et al., 2001; Bhargava and Singh, 1981; Geetha et al., 2004; Jayasekara et al., 2005; Meyer et al., 2008; Ojewole, 2008; Perrett et al., 1994; Perrett et al., 1995a; Perrett et al., 1995b; Rakuambo et al., 2006). Phytochemical characterization showed that these plants contains alkaloids, coumarin, isoflavones, methyl salicylate, phenol, saponins, tannins, terpenoids, xanthones (Ancolio et al., 2002; Asomaning et al., 1998; Jayasekara et al., 2002; Kandeda, 2007; Martinez et al., 1982; Meyer et al., 2008) (Table 1). Though a lot of pharmacological studies were done with these plants, very few were done to study their sedative and anticonvulsant activity (Adeyemi et al., 2010), for Adeyemi only worked with S. longepedunculata, and in addition he did not used the two main anticonvulsant tests (maximal electroshock and pentyletetrazol) that are very predictive for the type of epilepsy. Furthermore natural health products of vegetable origin have shown promise for the prevention of chronic diseases (Haddad et al., 2005; Hazem and AlaaEldin 2008). The present study was undertaken to look for the anticonvulsant and sedative properties of the three plants used in traditional medicine in Cameroon to treat insomnia and epilepsy.

\section{Materials and Methods Plant material}

A voucher specimen of each plant: $M$. thonningii (20134/SRF/Cam), O. sanctum (46702/HNC/Cam) and S. longepedunculata (10410/SRF/Cam) was authenticated and deposited at the National Herbarium of Cameroon in Yaoundé.

\section{Methanolic extract of M. thonningii}

Dried seeds of $M$. thonningii were ground. $1.45 \mathrm{~kg}$ of powder was macerated at room temperature in 3 liters of methanol for 72 hours. The mixture was filtered with Watman $n^{\circ} 1$ filter paper and evaporated at $80^{\circ} \mathrm{C}$. $230 \mathrm{~g}$ of the methanolic extract were obtained (yield 15.86\%). The M. thonningii methanolic extract was diluted in dimethyl sulfoxide (DMSO) $20 \%$ in distilled water before use and administered intraperitoneally (ip).

\section{Ethanolic extract of 0 . sanctum}

The powder of dried root barks of $O$. sanctum $(1200 \mathrm{~g})$ was macerated for 72 hours in 3 liters of ethanol $\left(95^{\circ} \mathrm{C}\right)$. The supernatant filtrated and evaporated to dryness at $50^{\circ} \mathrm{C}$ with a Rota vapor gave $147 \mathrm{~g}$ of extract (yield: $12.25 \%$ ). The extract of $O$. sanctum was diluted in distilled water before use (ip administration).

\section{Aqueous extract of $S$. longepedunculata}

$200 \mathrm{~g}$ of powder of dried roots of $\mathrm{S}$. longepedunculata were macerated in $200 \mathrm{ml}$ of distilled water for 48 hours at room temperature. After filtration with a Watman $n^{\circ} 1$ filter paper, the supernatant was evaporated to dryness using a Rota vapor at a temperature of $45^{\circ} \mathrm{C}$. $11 \mathrm{~g}$ of the aqueous extract was obtained (yield: $5.5 \%$ ). The extract was diluted in distilled water before use (oral administration).

All the extracts were prepared according to traditional healers and chemists, and were administered 1 hour before the tests at the following doses $100,200,500$ and $1000 \mathrm{mg} / \mathrm{kg}$.

\section{Animals}

Adult male mice: Mus musculus Swiss $22 \pm 3 \mathrm{~g}, 2$ months old and obtained from the animal laboratory of our University were used for this study. Animals were housed in standard cages at $25^{\circ} \mathrm{C}$, on a $12 / 12 \mathrm{~h}$ light-dark cycle. They were supplied with food and water ad libitum. Mice were divided into 6 groups (except for the diazepam-induced sleep test that had 5 groups). One negative control group received a vehicle (distilled water or DMSO $20 \%$ in distilled water), one positive control group received an appropriate well-known anticonvulsant substance as a reference and four test groups received different doses of the plant extracts. Drugs were administered in a volume of $10 \mathrm{ml} / \mathrm{kg}$ of body weight. All animal experiments were carried out in accordance with the National ( $\mathrm{N}^{\circ}$.FWA-IRB00001954) and the United States Guide for the Care and Use of Laboratory Animals, US National Research Council (USNRC, 1996).

\section{Diazepam-induced sleep test}

Mice were divided into five groups of 6 or 10 mice and received different treatments. Group I (negative control) was treated with distilled water or DMSO $20 \%$ in distilled water. Groups II to V (test groups) were treated with 4 doses of the plant extracts. The sleep potentiating effects of the plant extracts were studied in mice that had received diazepam (ip) at a dose of $50 \mathrm{mg} / \mathrm{kg} 1$ hour after treatment. The time taken from the loss of the straightening reflex to its regain gave the sleeping time (Beretz et al., 1978; Ngo Bum et al., 2009ab; Rakotonirina et al., 2001). The straightening reflex (defined as a movement of the forehand that is on the same side as the stimulated ear) was obtained in the awakening mice by stimulating the external ear of the mouse with horsehair. 


\section{Maximal electroshock (MES) test}

Mice were divided into six groups of 6 or 10 mice each and received different treatments. Group I (negative control) was treated with distilled water or DMSO $20 \%$ in distilled water. Groups II to V (test groups) were treated with 4 doses of the plant extracts. Group VI treated with diazepam, $5 \mathrm{mg} / \mathrm{kg}$ ip. was used as positive control. Tonic convulsions of the hind extremities of mice were induced by passing an alternating electrical current $(50 \mathrm{~Hz}, 30 \mathrm{~mA}, 0.2 \mathrm{~s})$ through eye electrodes (Bernasconi et al., 1988; Lehmann et al., 1988; Ngo Bum et al., 2001; Ngo Bum et al., 2009ab; Schmutz et al., 1990; Wamil et al., 1994). The number of animals protected from tonic hind limb extension was determined in each dose group.

\section{N-methyl-D-aspartate (NMDA) test}

Mice were divided into six groups of 10 mice and treated as above. Except that here the positive control group received $33 \mathrm{nmol} / \mathrm{kg}$ of d-2-amino-7-phosphonoheptanoate (D-AP7). Turning behaviour was induced in mice by the subcutaneous (s.c.) injection of NMDA $75 \mathrm{mg} / \mathrm{kg}, 1 \mathrm{~h}$ after treatment's administration. Mice were observed for $30 \mathrm{~min}$. Animals which did not exhibit turning behaviour within $30 \mathrm{~min}$ were declared protected. Turning behaviour was characterised by two consecutive $360^{\circ}$ cycles fulfilled by the same animal (Ngo Bum et al., 2001; Ngo Bum et al., 2004; Ngo Bum et al., 2010).

\section{Strychnine (STR) test}

Six groups of 6 or 10 mice each were treated as above. Except that the positive control group received 3 $\mathrm{mg} / \mathrm{kg}$ clonazepam (ip). STR convulsions followed by death were induced in mice by the ip injection of $2.5 \mathrm{mg} / \mathrm{kg}$ STR nitrate. A protective effect of the different treatments given $1 \mathrm{~h}$ prior to STR was recorded. Animals which survived more than 10 min were qualified protected (Bernasconi et al., 1988; Lehmann et al., 1988; Ngo Bum et al., 2004; Ngo Bum et al., 2005).

\section{Pentylenetetrazol (PTZ) test}

Six groups of 6 or 10 mice each were treated as above. However the positive control group received 0.1 $\mathrm{mg} / \mathrm{kg}$ clonazepam ip. Clonic seizures were induced in mice by the ip injection of $70 \mathrm{mg} / \mathrm{kg} \mathrm{PTZ}$. The protective effect of the different treatments given $1 \mathrm{~h}$ before PTZ injection was recorded. Animals that did not convulse within the 10 min of observation were qualified protected (Bernasconi et al., 1988; Lehmann et al., 1988; Ngo Bum et al., 2001; Ngo Bum et al., 2010; Schmutz et al., 1990; Wamil et al., 1994).

\section{Picrotoxine (PIC) test}

Six groups of 6 or 10 mice each were treated as above. However the positive control group received 0.4 $\mathrm{mg} / \mathrm{kg}$ clonazepam ip. Clonic seizures were induced in mice by the ip injection of $7.5 \mathrm{mg} / \mathrm{kg}$ PIC. Mice were observed for $15 \mathrm{~min}$. A protective effect of the different treatments given $1 \mathrm{~h}$ before PIC-induced clonic seizures was recorded. Animals that did not convulse within 15 min of observation were qualified protected (Bernasconi et al., 1988; Lehmann et al., 1988; Ngo Bum et al., 2001; Ngo Bum et al., 2005).

\section{Isonicotinic hydrazide acid (INH) test}

Six groups of 6 mice each were treated as above. Except that the positive control group received diazepam $10 \mathrm{mg} / \mathrm{kg}$ p.o. Animals were injected ip with $\mathrm{INH} 250 \mathrm{mg} / \mathrm{kg} 1 \mathrm{~h}$ after the different treatment's administration and the time to the onset of clonic or tonic seizures was recorded (Bernasconi et al., 1988; Ngo Bum et al., 2001; Ngo Bum et al., 2010).

\section{Chemicals}

Clonazepam: (Rivotril $\AA$, was from Roche Pharma, Reinach Schweiz); Diazépam: (Valium $®$, was from Roche, Neuilly, France); d-2-amino-7-phosphonoheptanoate, Isonicotinic hydrazide acid, n-methyl-d-aspartate, pentylenetetrazol, picrotoxine and strychnine: (Sigma Aldrich Inc., St Louis, MO, USA).

\section{Statistical analysis}

Three parameters were measured: the protection against MES and chemically-induced seizures, the latency to the onset of seizures in INH test and the sleeping time. The percentage of protected animals were analysed using the Fisher Exact Test (two-tail). The analyses of variance (ANOVA) followed by Dunnett (HSD) were done for the latency to the onset of seizures in INH test and the sleeping time. Data were $p<0.05$ were qualified significant. The ED 50 were determined with Statgraphics Plus (confident limits at 95\%). 


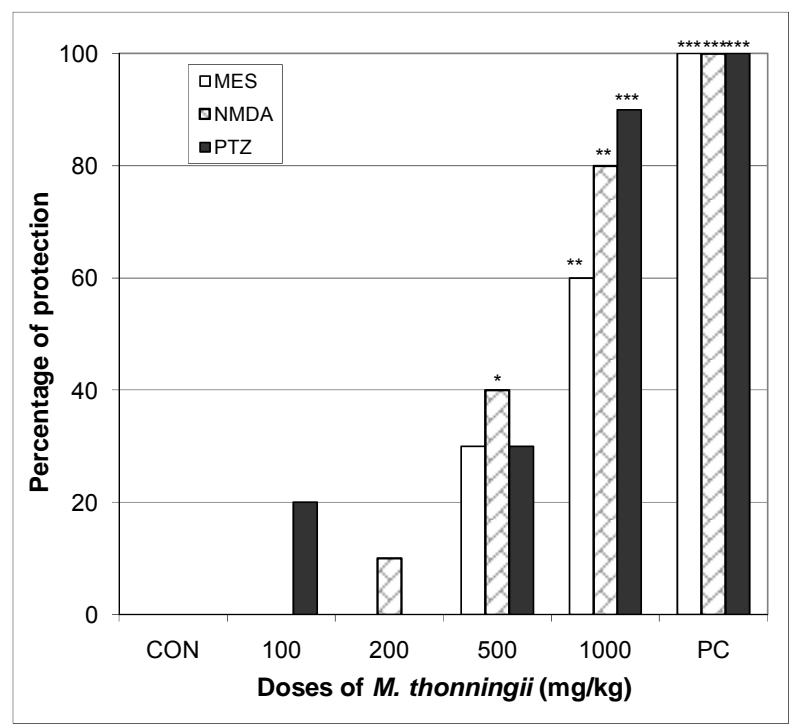

Figure 1: Effect of $M$. thonningii on electrically and chemically-induced convulsions in mice.

The results are expressed as the percentage of mice protected against convulsions. CON = DMSO $20 \%$ in distilled water, $\mathrm{PC}=$ diazepam $5 \mathrm{mg} / \mathrm{kg}$ for MES test, d-2-amino-7-phosphonoheptanoate $33 \mathrm{\eta mol} / \mathrm{kg}$ for NMDA test and clonazepam $0.1 \mathrm{mg} / \mathrm{kg}$ for PTZ test. $\mathrm{N}=10$ per dose, ${ }^{*} p<0.05,{ }^{* *} p<0.01$, ${ }^{* *} p<$ 0.001 vs CON, Fisher Exact Test (two-tail).

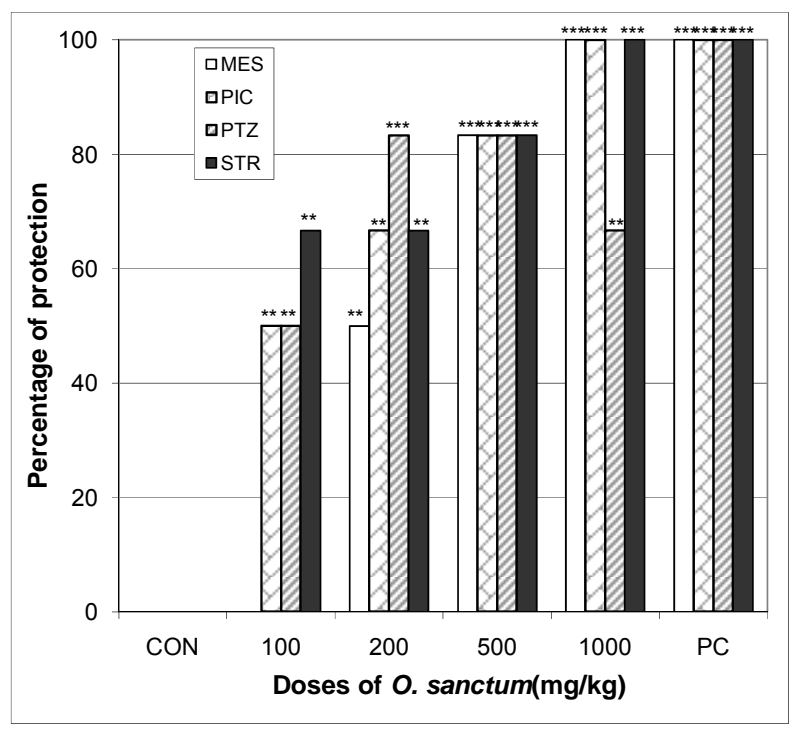

Figure 2: Effect of $O$. sanctum on electrically and chemically-induced convulsions in mice.

The results are expressed as the percentage of mice protected against convulsions. $\mathrm{CON}=$ distilled water, PC = diazepam $5 \mathrm{mg} / \mathrm{kg}$ for MES test, clonazepam $0.4 \mathrm{mg} / \mathrm{kg}$ for PIC test, clonazepam $0.1 \mathrm{mg} / \mathrm{kg}$ for PTZ test and clonazepam $3 \mathrm{mg} / \mathrm{kg}$ for STR test. $\mathrm{N}=6$ per dose, ${ }^{* *} p<0.01,{ }^{* * *} p<0.001$ vs CON, Fisher Exact Test (two-tail). 


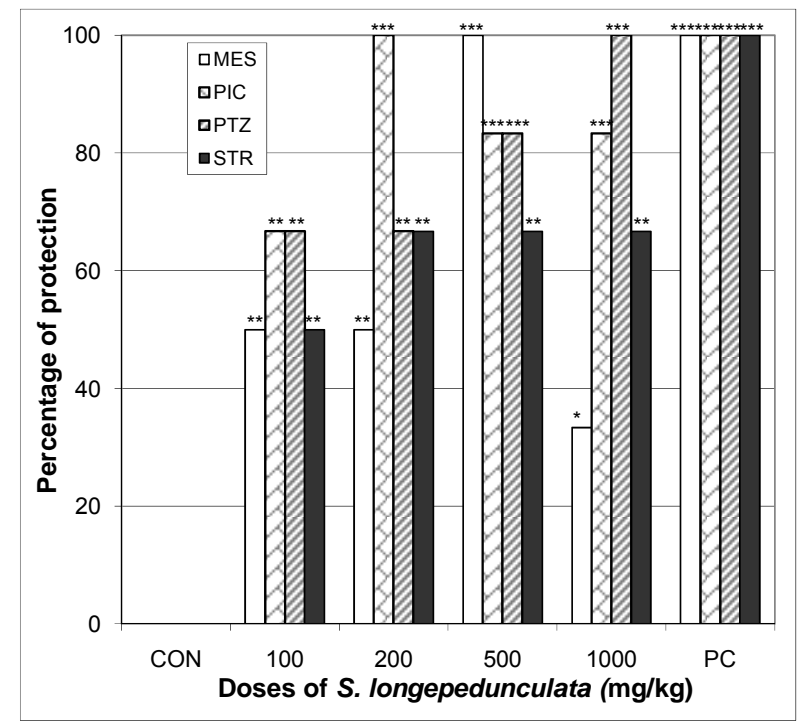

Figure 3: Effect of S. longepedunculata on electrically and chemically-induced convulsions in mice.

The results are expressed as the percentage of mice protected against convulsions. $\mathrm{CON}=$ distilled water, $\mathrm{PC}=$ diazepam $5 \mathrm{mg} / \mathrm{kg}$ for MES test, clonazepam $0.4 \mathrm{mg} / \mathrm{kg}$ for PIC test, clonazepam $0.1 \mathrm{mg} / \mathrm{kg}$ for PTZ test and clonazepam $3 \mathrm{mg} / \mathrm{kg}$ for STR test. $\mathrm{N}=6$ per dose, ${ }^{*} \mathrm{p}<0.05,{ }^{* *} \mathrm{p}<0.01,{ }^{* * *} \mathrm{p}<0.001$ vs CON, Fisher Exact Test (two-tail).

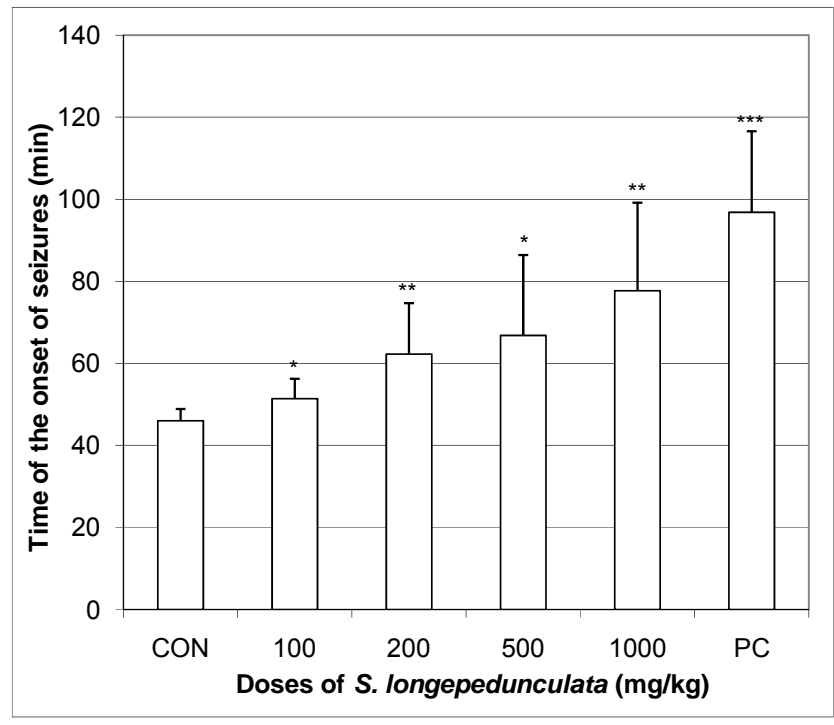

Figure 4: Effect of S. longepedunculata on INH-induced convulsions in mice.

The results are the time $(\mathrm{min})$ to the onset of seizures. They are expressed as means $\pm \mathrm{SEM}$. CON $=$ distilled water, $\mathrm{PC}=$ diazepam $10 \mathrm{mg} / \mathrm{kg} . \mathrm{N}=6$ per dose. ${ }^{*} \mathrm{p}<0.05$, ${ }^{* *} \mathrm{p}<0.01,{ }^{* \star *} \mathrm{p}<0.001 \mathrm{vs} \mathrm{CON}$, Anova followed by Dunnett (HSD). 


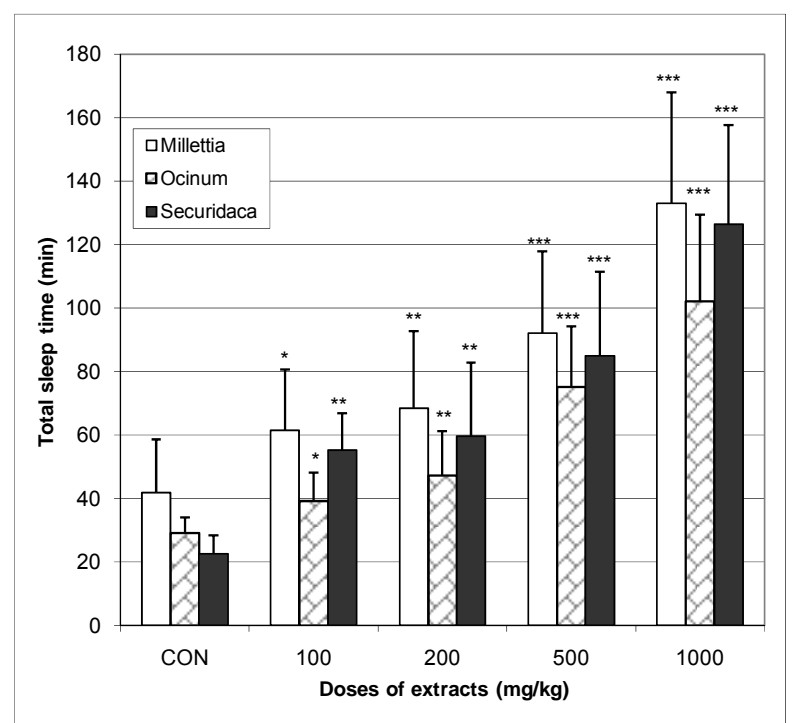

Figure 5: Effect of $M$. thonningii, O. sanctum and S. longepedunculata on diazepam-induced sleep in mice.

The results are the total sleep time $(\mathrm{min})$ induced by diazepam $(50 \mathrm{mg} / \mathrm{kg}$, i.p.) in the presence of different extracts in mice. They are expressed as means \pm SEM. CON $=$ distilled water or DMSO $20 \%$ in distilled water. $\mathrm{N}=6$ or 10 per dose. ${ }^{*} \mathrm{p}<0.05$, ${ }^{* *} \mathrm{p}<0.01,{ }^{* *} \mathrm{p}<0.001$ vs CON, Anova followed by Dunnett (HSD).

\section{Results}

\section{Effects of M. thonningii}

The methanolic extract of $M$. thonningii at a dose of $1000 \mathrm{mg} / \mathrm{kg}$ protected $60 \%$ of mice against MESinduced seizures $(p<0.05)$ and $90 \%$ of mice against PTZ-induced seizures $(p<0.001)$. M. thonningii also protected $80 \%$ of mice against NMDA-induced turning behavior $(p<0.01)$ (Fig. 1). The ED $D_{50}$ were $646(574-717)$ $\mathrm{mg} / \mathrm{kg}$ in NMDA test and 596(189-1004) $\mathrm{mg} / \mathrm{kg}$ in PTZ test. Controversially, M. thonningii failed to protect mice in PIC and STR tests. In diazepam-induced sleep test, the extract of $M$. thonningii multiplied by a factor of 3 the sleeping time of the control group (from $41 \pm 16 \mathrm{~min}$ to $133 \pm 34 \mathrm{~min}$ at a dose of $1000 \mathrm{mg} / \mathrm{kg}$ ) $[\mathrm{F}(5,44)=94 ; p<$ 0.001] (Fig. 5).

\section{Effects of $O$. sanctum}

The aqueous extract of $O$. sanctum protected mice in a dose dependant manner against convulsions. Like the known anticonvulsant compounds, $O$. sanctum at dose of $1000 \mathrm{mg} / \mathrm{kg}$ provided full protection against MES, PIC and STR-induced convulsions $(p<0.001)$. O. sanctum protected $83.3 \%$ of mice in PTZ test at the doses of 200 and $500 \mathrm{mg} / \mathrm{kg}$ ( $\mathrm{p}<0.01$ ) (Fig. 2). The $E D_{50}$ were 396(194-598) mg/kg in MES test, 283(27-538) $\mathrm{mg} / \mathrm{kg}$ in PIC test, 308(0-705) $\mathrm{mg} / \mathrm{kg}$ in PTZ test and 263(0-561) mg/kg in STR test. In diazepam-induced sleep test, the extract of $O$. sanctum multiplied by a factor of 3 the sleeping time of the control group (from $29 \pm 5$ min to $102 \pm 27 \mathrm{~min}$ at a dose of $1000 \mathrm{mg} / \mathrm{kg})[\mathrm{F}(5,24)=104 ; \mathrm{p}<0.001]$ (Fig. 5).

\section{Effects of S. longepedunculata}

The aqueous extract of $S$. longepedunculata strongly protected mice against convulsions. Like clonazepam, S. longepedunculata at a dose of $200 \mathrm{mg} / \mathrm{kg}$ provided full protection against PIC-induced seizures ( $p$ $<0.001$ ). At doses of 500 and $1000 \mathrm{mg} / \mathrm{kg}, S$. longepedunculata completely protected mice against MES and PTZ-induced convulsions $(p<0.001)$ and $(p<0.001)$, respectively. $66.6 \%$ of mice were protected in STR test $(p<$ 0.01) (Fig. 3). The ED50 were 351(0-824) $\mathrm{mg} / \mathrm{kg}$ in MES test, 264(0-674) mg/kg in PIC test and 263(0-561) mg/kg in PTZ test. In addition, S. longepedunculata significantly delayed the time of the onset of seizures in INH test $[F(6,41)=103 ; p<0.001]$ (Fig. 4). In diazepam-induced sleep test, the extract of S. Iongepedunculata multiplied by a factor superior to 5 the sleeping time of the control group (from $22 \pm 5 \min$ to $126 \pm 31 \mathrm{~min}$ at a dose of 1000 $\mathrm{mg} / \mathrm{kg})[\mathrm{F}(5,24)=154 ; \mathrm{p}<0.001]$ (Fig. 5). 
Table 1: Parts of the plant, form of the medicine and diseases treated in traditional medicine, chemical characterization and pharmacological activity.

\begin{tabular}{|c|c|c|c|c|c|c|c|}
\hline $\begin{array}{l}\text { Name of } \\
\text { the plant }\end{array}$ & $\begin{array}{l}\text { Part of the } \\
\text { plant used }\end{array}$ & $\begin{array}{l}\text { Form of } \\
\text { the } \\
\text { medicine }\end{array}$ & Diseases & Country & $\begin{array}{l}\text { Chemical } \\
\text { characterization }\end{array}$ & Pharmacological activity & References \\
\hline M. thonningii & $\begin{array}{l}\text { Roots } \\
\text { Barks } \\
\text { Leaves } \\
\text { Seeds }\end{array}$ & $\begin{array}{l}\text { Decoction } \\
\text { Washing } \\
\text { Infusion }\end{array}$ & $\begin{array}{l}\text { Epilepsy, fevers, heartaches, } \\
\text { pneumonia, cold, stomach aches, } \\
\text { rheumatism, headaches, pains, } \\
\text { allergy, worms, anti-venomous, } \\
\text { dysentery, insomnia. }\end{array}$ & $\begin{array}{l}\text { Cameroon } \\
\text { Central Africa } \\
\text { West Africa }\end{array}$ & Coumarin, Isoflavones & Molluscicidal Antischistosomal Insecticidal & $\begin{array}{l}\text { Ancolio et al., 2002; Arbonnier, } \\
\text { 2000; Belmain et al., 2001; Hutchinson } \\
\text { and Dalziel 1958; Geetha et al., 2004; } \\
\text { Perrett et al., 1994; Singhal et al., 1982; } \\
\text { Vyawahare et al., 2007 }\end{array}$ \\
\hline O. sanctum & $\begin{array}{l}\text { Leaves } \\
\text { Roots } \\
\text { Root barks }\end{array}$ & Decoction & $\begin{array}{l}\text { Epilepsy, insomia headaches, } \\
\text { fever, stomachaches, asthma, } \\
\text { allergy, itch, cough }\end{array}$ & $\begin{array}{l}\text { Cameroon } \\
\text { Central Africa } \\
\text { Vietnam } \\
\text { Thailand } \\
\end{array}$ & $\begin{array}{l}\text { Terpenoids Phenol, } \\
\text { Tannins } \\
\text { Akaloids Saponins }\end{array}$ & $\begin{array}{l}\text { Hypotensive Myorelaxant } \\
\text { Anti-stress Cardiac depressant }\end{array}$ & $\begin{array}{l}\text { Abbiw, 1990; Gupta et al., 2007; } \\
\text { Kandeda, 2007; Martinez et al., 1982; } \\
\text { Perrett et al., 1995a }\end{array}$ \\
\hline S. longepedunculata & $\begin{array}{l}\text { Roots } \\
\text { Barks } \\
\text { Leaves }\end{array}$ & & $\begin{array}{l}\text { Epilepsy, insomnia, pains, anti- } \\
\text { venomous, worms, rheumatism, } \\
\text { jaundice, bronchitis, itch, } \\
\text { intestinal obstruction, } \\
\text { tuberculosis, leprosies, cough, } \\
\text { fever, constipation, conjunctivitis, } \\
\text { cataract, anti-venomous }\end{array}$ & $\begin{array}{l}\text { Cameroon } \\
\text { Central Africa } \\
\text { East Africa }\end{array}$ & $\begin{array}{l}\text { Xanthones, Methyl } \\
\text { salicylate } \\
\text { Alkaloids }\end{array}$ & $\begin{array}{l}\text { Antinociceptive, antidepressant, sedative, } \\
\text { insecticidal, trypanocidal, analgesic, } \\
\text { tonic, anti-malarial, } \\
\text { anti-inflammatory } \\
\text { anticonvulsant }\end{array}$ & $\begin{array}{l}\text { Adebiyi et al., 2006; Aderbauer et al., } \\
\text { 2008; Adeyemi et al., 2010; Asomaning et } \\
\text { al., 1998; Bhargava and Singh, 1981; } \\
\text { Invine, 1961; Jayasekara et al., 2005; } \\
\text { Meyer et al., 2008; Ojewole, 2008; Perrett } \\
\text { et al., 1995b; Rakuambo et al., } 2006\end{array}$ \\
\hline
\end{tabular}




\section{Discussion}

O. sanctum and S. longepedunculata protected 66.7 to $100 \%$ of STR-induced convulsions with $O$. sanctum being the most effective. The inhibition of STR-induced seizures suggested the presence of anticonvulsant properties (Adeyemi et al., 2010; Mustafa and Ali, 2008) and the involvement of glycine receptors (Findlay et al., 2002) in the two plants. The lack of effect of $M$. thonningii in STR test reveal that this extract might not mediate its anticonvulsant effect via glycine receptors. The extract of $M$. thonningii strongly antagonized NMDA-induced turning behaviour. Since NMDA receptor antagonists have been shown to possess anticonvulsant and antiepileptic properties in several animal models of epilepsy (Davies et al., 1986; Ngo Bum et al., 1996), it can be suggested that the anticonvulsant properties of $M$. thonningii could be mediated by NMDA receptors. The extracts of $O$. sanctum and $S$. longepedunculata completely protected mice against the convulsions induced by PIC while M. thonningii failed to protect mice in PIC test. This result suggested that, the anticonvulsant activity of M. thonningii could not be related to the picrotoxin site of the GABA receptor complex (Mustafa and Ali, 2008). In INH test, S. longepedunculata prolonged the time of the onset of convulsions. The extracts of $M$. thonningii, $O$. sanctum and S. longepedunculata protected mice against PTZ-induced convulsions, with S. longepedunculata being the most effective. The antagonism of INH and PTZ-induced seizures suggested the presence of anticonvulsant properties and the interaction of the plant extracts with the GABA-ergic neurotransmission (Mustafa and Ali, 2008; Pérez-Saad and Buznego, 2008). Finally, all three extracts inhibited MES-induced convulsions by probably prolonging the inactivation of sodium channels (Holmes, 2007). The MES and PTZ tests are of predictive relevance considering the clinical spectrum of activity of experimental compounds (Kupferberg and Schmutz, 1997). They are assumed to identify anticonvulsant drugs effective against generalized tonic-clonic/ partial seizures and generalized clonic seizures, respectively (Holmes, 2007; Kupferberg and Schmutz, 1997). Therefore the effect of the extracts of $M$. thonningii, $O$. sanctum and S. longepedunculata in these tests could suggest anticonvulsant efficacy against the afore-mentioned seizures types in man. In addition, M. thonningii, $O$. sanctum and S. longepedunculata seemed to possess sedative properties for they strongly increased, and in a dose-dependent manner the sleeping time induced by diazepam (Rakotonirina et al., 2001; Ngo Bum et al., 2009a). The sedative properties of these plants could be related to the presence of some components in the extracts activating the benzodiazepine and/or GABA receptors in the GABA receptor complex (Rang et al., 1999). In conclusion, this study allowed showing that the purported sedative and anticonvulsant activity of $M$. thonningii, $O$. sanctum and $S$. longepedunculata are real and that they could be helpful in the treatment of insomnia and epilepsy in traditional medicine in Africa and particularly in Cameroon. In the future, isolation of active constituents of the plant extracts could pave the way for the standardization of biologically active compound as in the case of Turnera aphrodisiac Ward (Kumar and Sharma, 2005; Rabbani et al., 2008) and could be helpful to cure insomnia, epilepsy, intractable epilepsy or other brain diseases.

Abbreviations: Maximal electroshock (MES), N-methyl-D-aspartate (NMDA), Pentylenetetrazol (PTZ), Picrotoxin (PIC), Strychnine (STR), Negative control (CON), Positive control (PC).

\section{Acknowledgement}

This work was supported by the University of Ngaoundéré in Cameroon who provided for animals, drugs and equipments.

\section{References}

1. Abbiw, D.K., (1990). Useful plants of Ghana. Kew: Intermediate technology publication and the royal botanic garden, London.

2. Adebiyi, R.A, Elsa A.T., Agaie B.M., Etuk E.U. (2006). Antinociceptive and antidepressant like effects of Securidaca longepedunculata root extract in mice. J. Ethnopharmacol. 107:234-239.

3. Aderbauer, B., Clausen, P.H., Kershaw, O., Melzig, M.F. (2008). In vitro and in vivo trypanocidal effect of lipophilic extracts of medicinal plants from Mali and Burkina Faso. J. Ethnopharmacol. 119:225-231.

4. Adeyemi, O.O., Akindele, A.J., Yemitan, O.K., Aigbe, F.R., Fagbo, F.I. (2010). Anticonvulsant, anxiolytic and sedative activities of the aqueous root extract of Securidaca longepedunculata Fresen. $\mathrm{J}$. Ethnopharmacol. 130:191-195.

5. Ancolio, C., Azas, N., Mahiou, V., Ollivier, E., Di Giorgio, C., Keita, A., Timon-David, P., Balansard, G. (2002). Antimalarial activity of extracts and alkaloids isolated from six plants used in traditional medicine in Mali and Sao Tome. Phytother. Res. 16:646-649.

6. Arbonnier, M. (2000). Arbres, arbustes et lianes des zones sèches d'Afrique de l'Ouest. Ed. Centre de Coopération Internationale en Recherche Agronomique pour le développement/Muséum national d'histoire naturelle/Union mondiale pour la nature (CIRAD/MNHN/UICN), Paris 
7. Asomaning, W.A., Otoo, E., Akoto, O., Oppong, I.V., Mensah, I.A., Waibel, R., Achenbach, H. (1998). Isoflavanes and coumarins from Milletia thonningii. Phytochemistry 51:937-941.

8. Bhargava, K.P., Singh, N. (1981). Anti-stress activity of Ocinum sanctum Linn. Indian. J. Med. Res. 73:443-451.

9. Belmain, S.R., Neal, G.E., Ray, D.E., Golob, P. (2001). Insecticidal and vertebrate toxicity associated with ethnobotanicals used as post-harvest protectants in Ghana. Food. Chem. Toxicol. 39:287-291.

10. Beretz, A., Haag-Berrurier, M. (1978). Anton R. Choix de méthodes pharmacologiques pour l'étude des activités de l'aubépine. Plantes médicinales et phytothérapie 4:305-314.

11. Bernasconi, R., Klein, M., Martin, P., Christen, P., Hafner, T., Portet, C., Schmutz, M. (1988). GammaVinyl GABA: comparison of neurochemical and anticonvulsant effects in mice. J. Neural. Transm. 72:213233.

12. Davies, J., Evans, R.H., Herrling, P.L., Jones, A.W., Olverman, H.J., Pook, P., Watkins, J.C. (1986). CPP, a new potent and selective NMDA antagonist. Depression on central neuron responses, affinity for [3H]D-AP5 binding sites on brain membranes and anticonvulsant activity. Brain Res. 382:169-173.

13. Findlay, G.S., Wick, M.J., Mascia, M.P., Wallace, D., Millier, G.W., Harris, R.A., Blednov, Y.A. (2002). Transgenic expression of a mutant glycine receptor decreases alcohol sensitivity of mice. J. Pharmacol. Exp. Ther. 300:526-534.

14. Geetha, R., Kedlaya, Vasudevan, D.M. (2004). Inhibition of lipid peroxidation by botanical extracts of Ocimum sanctum: In vivo and in vitro studies. Life Sci. 76:21-28.

15. Gupta, P., Kumar, D.Y., Babu, K.S., Guatam, P., Rakesh, M. (2007). Constituents of Ocimum sanctum with Antistress Activity. J. Nat. Prod. 70:1410-1416.

16. Haddad, P.S., Azar, G.A., Groom, S., Boivin, M. (2005). Natural health products, modulation of immune function and prevention of chronic diseases. Evidence-based Complem. Altern. Med. 2:513-520.

17. Hazem, A.H.K. and AlaaEldin, A.H. (2008). Red Cabbage (Brassica oleracea) Ameliorates Diabetic Nephropathy in Rats. Evidence-based Complem. Altern. Med. 5:281-287.

18. Holmes, G.L. (2007). Animal model studies application to human patients. Neurology. 69:S28-S32.

19. Hutchinson, J. Dalziel, J.M. (1958). The flora of West Tropical Africa. Crown Agents for Overseas Governments and Administration, London.

20. Irvine, F.R. (1961). Woody plants of Ghana. Oxford University Press, London.

21. Jayasekara, T.K., Stevenson, P.C., Belmain, S.R., Farman, D.I., Hall, D.R. (2002). Identification of methyl salicylate as the principal volatile component in the methanol extract of root bark of Securidaca longepedunculata Fers. J. Mass. Spectrom. 37:577-580.

22. Jayasekara, T.K., Stevenson, P.C., Hall ,D.R., Belmain, S.R. (2005). Effect of volatile constituents from Securidaca longepedunculata on insect pests of stored grain. J. Chem. Ecol. 31:303-313.

23. Kandeda, K.A. (2007). Anticonvulsant and sedative properties of the ethanolic extract of roots of Ocimum sanctum Lam (Lamiaceae) in mice. Mater Degree's Thesis; University of Ngaoundere, Cameroon.

24. Kupferberg, H.J., Schmutz, M. (1997). Screening of new compounds and the role of the pharmaceutical industry. In: Engel J, Pedley TA, editors. Epilepsy: A Comprehensive Textbook. Philadelphia, New York: Lippincott-Raven: 1417-1434.

25. Kumar, S, Sharma, A. (2005). Anti-anxiety activity studies on homoeopathic formulations of Turnera aphrodisiaca Ward. Evidence-based Complem. Altern. Med. 2:117-119.

26. Lehmann, J., Hutchison, A., McPherson, S.E., Mondadori, C., Schmutz, M., Sinton, C.M., Tsai, C., Murphy, D.E., Steel, D.J., Williams, M., Cheney, D.L., Wood, P.L. (1988). CGS 19755, a selective and competitive N-methyl-D-aspartate-type excitatory ammno acid receptor antagonist. J. Pharmacol. Exp. Ther. 246:65-75.

27. Martinez, O.E., Lwande, W., Delle, M.F., Marini, B.G.B. (1982). A pyrano-isoflavone from seeds of Milletia thonningii. Phytochemistry. 21:1763-1765.

28. Meyer, M.J.J., Rakuambo, N.C., Hussein, A.A. (2008). Novel xanthones from Securidaca longepedunculata with activity against erectile dysfunction. J. Ethnopharmacol. 119:599-603.

29. Mustafa, A.M.S, Ali, A.M. (2008). A substance in broad beans (Vicia faba) is protective against experimentally induced convulsions in mice. Epilepsy Behav. 12:25-29.

30. Ngo Bum, E., Meier C.L., Urwyler, S., Wang, Y., Herrling, P. (1996). Extracts from rhizomes of Cyperus articulatus (cyperaceae) displace [3H]CGP39653 and $[3 \mathrm{H}]$ glycine binding from cortical membranes and selectively inhibit NMDA receptor-mediated neurotransmission. J. Ethnopharmacol. 54:103-111.

31. Ngo Bum, E., Schmutz, M., Meyer, C., Rakotonirina, A., Bopelet, M., Portet ,C., Jeker, A., Rakotonirina, S.V., Olpe, H.R., Herrling, P. (2001). Anticonvulsant properties of the methanolic decoction of Cyperus articulatus (Cyperaceae). J. Ethnopharmacol. 76:145-150.

32. Ngo Bum, E., Dawack, D.L., Schmutz, M., Rakotonirina, A., Rakotonirina, S.V., Portet, C., Jeker, A., Olpe, H.R., Herrling, P. (2004). Anticonvulsant activity of Mimosa pudica decoction. Fitoterapia. 75:310-315.

33. Ngo Bum, E., Naami, Y.F.C., Soudi, S., Rakotonirina, S.V., Rakotonirina, A. (2005). Psorospermum febrifugum spach (Hypericaceae) decoction antagonized chemically- induced convulsions in mice. Int. J. Pharmacol. 1:118-121.

34. Ngo Bum, E., Taiwe, G.S, Nkainsa, L.A., Moto, F.C.O., Seke Etet, P.F., Hiana, I.R., Bailabar, T., Rouyatou, Papa Seyni, Rakotonirina, A., Rakotonirina, S.V. (2009a). Validation of anticonvulsant and sedative activity of six medicinal plants. Epilepsy Behav. 14:454-458. 
35. Ngo Bum, E., Taiwe, G.S., Moto, F.C.O., Ngoupaye, G.T., Nkantchoua, G.C.N., Pelanken, M.M., Rakotonirina, S.V., Rakotonirina, A. (2009b). Anticonvulsant, anxiolytic and sedative properties of the roots of Nauclea latifolia Smith in mice. Epilepsy Behav. 15:434-440.

36. Ngo Bum, E., Nkantchoua, G.N., Njifutie Njikam, Taiwe, G.S., Ngoupaye, G.T., Pelanken, M.M., Nanga, L., Maidawa, F., Rakotonirina, A., Rakotonirina, S.V. (2010). Anticonvulsant and Sedative activity of leaves of Senna spectabilis in mice. Int. J. Pharmacol. 6:123-128.

37. Ojewole, J.A.(2008). Analgesic, anti-inflammatory and hypoglycaemic effects of Securidaca longepedunculata (Fresen.) [Polygalaceae] root-bark aqueous extract. Inflammopharmacology 16:174-181.

38. Pérez-Saad, H., Buznego, M.T. (2008). Behavioral and antiepileptic effects of acute administration of the extract of the plant Cestrum nocturnum Lin (lady of the night). Epilepsy Behav. 12:366-372.

39. Perrett, S., Withfield, P.J., Bartlett, A., Sanderson, L. (1994). Attenuation of schistosoma mansoni cercariae with a molluscicide derived from Millettia thonningii. Parasitology. 109:559-63.

40. Perrett, S., Withfield, P.J. (1995). Aqueous degradation of isoflavonoids in an extract of Milletia thonningii (Leguminosae), which is larvicidal towards schistosomes. Phytotherapy Res. 9:401-404.

41. Perrett, S, Withfield, P.J., Sanderson, L., Bartlett, A. (1995). The plant molluscicide Milletia thonningii (Leguminosae) as a topical antischistosomal agent. J. Ethnopharmacol; 47:49-54.

42. Rabbani M., Sajjadi SE, Mohammadi A. (2008). Evaluation of the anxiolytic effect of Nepeta persica Boiss. in mice Evidence-based Complem. Altern. Med. 5:181-186.

43. Rakotonirina, S., Ngo Bum, E., Rakotonirina, A., Bopelet, M. (2001). Sedative properties of the decoction of the rhizome of Cyperus articulatus. Fitoterapia 72:22-29.

44. Rakuambo, N.C., Meyer, M.J.J., Hussein, A., Huyser, C., Mdlalose, S.P., Raidani, T.G. (2006). In vitro effect of medicinal plants used to treat erectile dysfunction on smooth muscle relaxation and human sperm. J. Ethnopharmacol. 105:84-88.

45. Rang, H.P., Dale, M.M., Ritter, J.M. (1999). Pharmacology. Churchill Livingstone; London, New York.

46. Schmutz, M., Portet, C., Jeker, A., Klebs, K., Vassout, A., Allgeier, H., Heckendorn, R., Fagg, G.E., Olpe, H.R., Van Riezen, H. (1990). The competitive NMDA receptor antagonists CGP 37849 and CGP 39551 are potent, orally-active anticonvulsants in rodents. Naunyn-Schmiedeberg's Arch. Pharmacol. 342:61-66.

47. Singhal, A.K., Sharma, R.P., Baruoh, J.N., Govindan, S.V., Hertz, W. (1982). Rotenoids from roots of Millettia pachycarpa. Phytochemistry. 21:949-951.

48. USNRC (1996). Guide for the Care and Use of Laboratory Animals, US National Research Council, Washinfton, D.C., USA.

49. Vyawahare, N.S., Khandelwal, A.R., Batra, V.R., Nikam, A.P. (2007). Herbal anticonvulsants. J. Herbal Medicine and Toxicology 1:9-14.

50. Wamil, A.W., Schmutz, M., Portet, C., Feldmann, K.F., McLean, M.J. (1994). Effects of Oxcarbazepine and 10-hydroxycarbamazepine on action potential firing and generalized seizures. Eur J Pharmacol. 271:301-308. 